\title{
EL DERECHO DE ASILO EN ESPAÑA DURANTE LA EDAD MODERNA*
}

POR

\author{
DANiel SÁnChez AguirReolea \\ Universidad de Navarra
}

\section{RESUMEN}

Después de una larga evolución medieval, sobre todo en los territorios peninsulares de mayor influencia castellana, el derecho de asilo quedó completamente definido, constituyendo una prerrogativa exclusiva de la Iglesia. Los ministros de la Iglesia defendieron este derecho, haciéndolo respetar durante tres siglos, enfrentándose incluso a las más altas autoridades civiles. Esta figura jurídica tuvo una efectividad real y cotidiana, constituyendo una de las salidas a las que primero acudían los delincuentes que pretendían eludir la justicia.

PALABRAS ClAVE: Derecho de asilo, Relaciones Iglesia-Estado, Jurisdicción Civil, Jurisdicción Eclesiástica, Delicuencia, Castilla, Navarra, Edad Moderna

\begin{abstract}
After a long medieval evolution, especially in the peninsular territories of greater Castilian influence, the right of asylum remained completely defined, and it became an exclusive prerogative of the Church. The ministers of the Church defended this right, and they caused to respect it during three centuries, and were faced even to the highhest civil authorities. This legal figure had a rou-
\end{abstract}

* Agradecemos su ayuda a Don José Luis Sales Tirapu y a Don Isidoro Ursua Irigoyen, archiveros del Archivo Diocesano de Pamplona. Este trabajo se incribe dentro del proyecto de investigación «Formas de vida modos de creer: hacia una historia cultural de Navarra, siglos XIV-XIX», financiado por el Gobierno de Navarra, y forma parte de la tesis doctoral que está elaborando el autor: «El asalto de caminos en la Navarra de la Edad Moderna: una perspectiva histórico-antropológica».

Mundo moderno Hispania Sacra 55 (2003) 
tine and real effectiveness, and it was one of the exits that the first the delinquents responded that intended to elude the justice.

KEY WORDS: Right of asylum, Church-Satae Relations, Civil Jurisdiction, Eclesiastical Jurisdiction, Delinquency, Castille, Navarre, Early Modern Age

\section{INTRODUCCIÓN}

El estudio del derecho de asilo a lo largo de la Edad Moderna ha recibido escasa atención por parte de la historiografia europea. Al tratarse, durante la Edad Moderna, de un fenómeno fundamentalmente católico, Francia y sobre todo Italia han sido los países en los que más se ha estudiado ${ }^{1}$. En el ámbito de Alemania o países anglosajones, tanto la Antigüedad como la Edad Media han sido los períodos que han suscitado mayor interés ${ }^{2}$. Este relativo vacío historiográfico, que también se da en España, contrasta con el interés social que siempre ha despertado esta cuestión, no sólo porque a nuestros ojos contemporáneos pueda parecer curiosa la impotencia de la justicia civil una vez atravesados los muros de una iglesia, sino porque esta figura jurídica tuvo una importancia real en estas sociedades. Así lo demuestran la gravedad de los conflictos que se dieron entre Iglesia y Estado por el control de esta jurisdicción, las numerosas obras y tratados que defendieron cada una de las posturas ${ }^{3}$, o la enorme cantidad de procesos

1 Vittorio de MARCO, «L'immunità ecclesiastica nel Regno di Napoli durante il XVII secolo: il caso delle diocesi di Puglia», en Ricerche di storia sociale e religiosa, 36 (1989), pp. 123-158; M.P. CARROLL, «Religion, ricelttizie and the immunity of southerm Italy of the Reformation», en Journal for the scientific study of religion, 31 (1992), pp. 247-260; Pierpaolo BONACINI, «Conti, vesconvi, abati: potere civile e immunità ecclesiastiche nel territorio modenese dell'Alto Medioevo", en Studi medievali, 30 (1989), pp. 823-837; K.L. REYERSON, «Flight from prosecution: the search for religious asylum in medieval Montpellier (France)», en French historical studies, 17 (1992), pp. 603-626; E. MAGNOU-NORTIER, «Etude sur le privilége d'immunité du IV au IX siècle», en Revue Mabillon Ligugé, 60 (1984), pp. 465-512.

2 B.H. ROESENWEIN, Negotiating space: power, restraint and privileges of immunity in early medieval Europe, Ithaca, Cornwell University Press, 1999; Wieslaw MOSSAKOWSKI, «The problems of the temple asylum genesis in the ancien Rome»; en Pomoeriumstucia et commentarii ad obrem classicum spectantia, 2 (1996), pp. 5-13.

3 Pedro CALDERÓN De LA BARCA, La inmunidad del sagrado. Edición crítica de José María Ruano de la Haz, Delia Gavela y Rafael Martín, Pamplona, Universidad de Navarra, 1997; Pío VIVES, Discurso apologético por la inmunidad y libertad, Barcelona, en casa de Ioseph Forcada..., 1652; Tommaso DEL BENE, Thomae Delbene Clerici Regularis ... De immunitate etiurisdictione ecclesiastica ...; pars prima, Auenione : sumptib. I. Piot ..., 1659; Pietro GAMBACORTA, Petri Gambauortae e Societate Iesu Commentariorum deimmunitate ecclesiarum in Constitutionem Gregorij XIV Pont Max libri octo, Lugduni : sumptibus Jacobi Carton \& Petri Cavellat, 1622; Prospero FARINACCI, Prosperi Farinacii... De immunitate ecclesiarum et confugientibusad eas ad interpretationem Bullae Gregorii XIV... , Lugduni : sumpt. Haered. Gab. Boissat \& Laurentij Anisson, 1642; Alexandro AMBROSINO, Commenta-

Mundo moderno

Hispania Sacra 55 (2003) 
judiciales que generaron distintos tribunales otorgando libertad e impunidad a un sinfin de delincuentes. Este trabajo ha centrado su estudio documental en Navarra, territorio particularmente interesante porque comparte una tradición jurídica similar a la de Aragón, defendida por la mayoría de las instituciones civiles, y una evolución especialmente influenciada por Castilla, impulsada por la Iglesia y los virreyes. Para ello se han utilizado los fondos del Archivo General de Navarra (A.G.N.) y del Archivo Diocesano de Pamplona (A.D.P.).

\section{ORIGEN: ENTRE INTERCESIÓN Y LUGAR SAGRADO}

Los privilegios del fuero clerical eran conocidos como inmunidad eclesiástica y abarcaban tres aspectos: inmunidad Real, que eximía de impuestos a la Iglesia y consideraba sus bienes como inalienables; inmunidad personal, que afectaba a cada uno de los clérigos, no teniendo que realizar el servicio militar y debiendo ser juzgados sólo por sus tribunales específicos, y, finalmente, la inmunidad local o derecho de asilo propiamente dicho 4 .

$\mathrm{R}$. Olaechea define asilo desde una acepción jurídico-canónica como «un lugar privilegiado en el que se encontraban defendidas o a cubierto ciertas categorías de personas susceptibles de ser perseguidas», siendo derecho de asilo «el privilegio o costumbre en virtud de la cual esos lugares se convertían en un refugio reconocido» ${ }^{5}$.

El derecho de asilo, tal y como lo conocemos en la Edad Moderna, fue producto de una larga evolución en la que convergieron diferentes tradiciones jurídicas y religiosas, a veces contradictorias. Existía un sustrato greco-romano según el cual algunos lugares, como ciertos templos o estatuas de emperadores, llegaron a gozar de inmunidad. La tradición germánica aportó una reconocida inmunidad para los templos paganos y cierta inviolabilidad de la casa llamada domfreyheit. La última tradición fue la comenzada por los Padres de la Iglesia, que impulsó la función de intercesión por parte de los clérigos y se cimentó en

ria in Bullam Greg. XIV. Pont. Max. De immunitate, et libertate ecclesiastica ..., Bracciani : Sumtibus Vincentii Castellani ..., 1633; Johannes Baptista Carmen FATTOLILlus, Theatrum immunitatis et libertatis ecclesiasticae juxta Constitutionem Benedictina iGregorianae ampliativam, de qua satis in prioribus tomis exaratum ac commentatum extat ..., Ex Typographia Petri Ferri propè Magnam Curiam Innocentianam Romae, 1730; AGENTS Généraux du Clergé de France, apport de l'Agence : contenant les principales affaires du Clergé, qui se sont passées l'année 1720 jusqu'en l'année 1725 / fait par ... l'abbé De Brancas ..., dans l'Assemblée generale du Clergé, tenue à Paris en l'année 1725. Avec les pieces justificatives dudit rapport, A Paris : chez Pierre Simon ..., 1726.

${ }_{4}$ Antonio Morgado García, Derecho de asilo y delincuencia en la diócesis de Cádiz: siglos XVII y XVIII, Cádiz: Diputación Provincial, 1991, p. 6.

5 R. OLAECHEA, «Anotaciones sobre la inmunidad local en el XVIII español», en Miscelánea Comillas, 46 (1966), p. 315. 
el arrepentimiento religioso, en la enmienda y en la mitigación de la pena civil ${ }^{6}$. A partir de la Edad Media, toda legislación contó con dos componentes principales, deudores de estas tres tradiciones. En algunos aspectos, como la defensa del débil frente a la venganza privada, prevaleció el principio de lugar sagrado e inviolable. Sin embargo, en delitos de deudas o fuga de esclavos, permaneció el de intercesión, abogando para que los reos no sufrieran castigos físicos graves, siendo entregados bajo juramento para poder dar satisfacción a la justicia.

En el año 392 se reconoció por primera vez el derecho de asilo de manera implícita al excluir de él a los deudores del fisco ${ }^{7}$. El Concilio de Orange de 441 en su canon V fue el primero en establecer que no se debía «sacar a los defendidos por reverencia e intercesión del lugar» ${ }^{8}$. La mayoría de los autores coincide al afirmar que su desarrollo se debió al clima generalizado de inseguridad que se abrió durante los primeros siglos de la Edad Media. Según esta teoría, el derecho de asilo se convirtió en una figura jurídica que cobijaba al débil frente a la venganza prïvada, en una época en que el Estado estaba poco desarrollado y la justicia era algo que sólo atañía a las personas implicadas ${ }^{9}$.

Las primeras leyes y cánones fueron concretando y acotando esta costumbre, siempre combinando las dos nociones de lugar sagrado y de intercesión por parte de los ministros ${ }^{10}$.

En España la primera ley que reconoció este derecho data del reinado de Gundemaro (610) ${ }^{11}$, siendo el XII Concilio de Toledo celebrado bajo Ervigio en el año 681 el que con mayor detalle lo estableció, adecuándolo a los problemas más cotidianos. Por ejemplo, se reservaron 30 pasos alrededor de las iglesias para que los allí refugiados pudieran atender a sus necesidades sin ensuciar ni causar molestias en el interior del templo o de los claustros ${ }^{12}$. Al mismo tiempo, se insistió en la labor de intercesión, así como en el respeto a la

\footnotetext{
${ }^{6}$ El episodio entre Jesús y la adúltera fue el más utilizado para defender y justificar la función intercesora que desempeñaban los clérigos.. "Quando el Redemptor intercedió por la adúltera, para que no la pedreassen, enseñó a sus ministros que debían pedir del mismo modo por los pecadores».

Fernando GONZÁlEZ DE SOCUEBA, Instrucción manual para la más breve expedición de los casos prácticos, y disputas de inmunidad local, Sevilla, Imprenta Geronymo de Castilla, 1766, p. 45.

7 Antonio MoRGado GARCÍA, Derecho de asilo..., p. 11.

8 Juan TEJADA Y RAMIRO, Colección de cánones y de todos los concilios de la iglesia española traducida al castellano con notas e ilustraciones, Madrid, Imprenta de Don Pedro Montero, 1855, Tomo I, p. 377.

9 R. OLAECHEA, «Anotaciones sobre la inmunidad local..., p. 318.

10 En el I Concilio de Orleáns del año 511, sólo se accedía a entregar al refugiado en caso de obtener por parte de su perseguidor el juramento de no dañar su vida o sus miembros. Se establecieron los casos de esclavos y raptores, que debían ser devueltos y puestos al servicio del perjudicado para resarcir el daño.

11 R. OLAECHEA, «Anotaciones sobre la inmunidad local..., p. 324.

12 Juan TEJADA Y RAMIRO, Colección de cánones..., Tomo I, p. 478.
} 
inviolabilidad de estos recintos, imponiéndose graves penas a quien incumpliera sus juramentos o quebrara el asilo con violencias o engaños.

\section{CONSOLIDACIÓN DEL DERECHO DE ASILO ECLESIÁSTICO Y DESAPARICIÓN DEL CIVIL}

\subsection{La legislación}

Según el tratadista de finales del XVIII González de Socueba, en los siglos XI y XII hubo un punto de inflexión en la concepción que la Iglesia tenía sobre el derecho de asilo. A partir de ese momento se pasó a considerar que esta figura jurídica se basaba únicamente en el respeto al recinto sagrado del templo, olvidándose de la faceta principalmente intercesora que en siglos anteriores tenía. Las primeras disposiciones en este sentido fueron tomadas por Gregorio VII en 1075, fundamentándose más coherentemente en el Decreto Graciano de $1140^{13}$, y reafirmándose durante el papado de Inocencio III (1198-1216) ${ }^{14}$.

A la extensión de esta mentalidad medieval que entendía el derecho de asilo de una manera más amplia ayudaron las circunstancias especiales de estos siglos. Por ejemplo, en Cuenca fue utilizado como un reclamo para colonizar las nuevas tierras, mientras que en Salamanca se utilizaba como un mecanismo de paz ante la inestable situación política y social. Gonzalo de Berceo (1198-1274) reflejó en su obra esta nueva concepción, «una fundamentación religioso-mítica del derecho de asilo, que quizás fuese necesaria para poder defenderlo ante la gran violencia reinante» ${ }^{15}$. En diferentes relatos la Virgen infringe castigos al que intenta quebrar el asilo y protege al acogido (Cantigas, 164 o 233).

Las leyes civiles también reaccionaron ante esta extensión del derecho de asilo y establecieron listas de los delitos graves que eximían del acogimiento. En la mayoría de los reglamentos de esta época se intentó asimilar el derecho de asilo a la inmunidad feudal y a los casos de corte, intentado variar su concepción, de derecho de la Iglesia, a derecho concedido por el rey a la Iglesia ${ }^{16}$.

Las leyes castellanas promulgadas por Alfonso X el Sabio también recogieron y adaptaron este privilegio. El Fuero Real (1255) eximía a los ladrones conocidos, incendiarios, quebrantadores de iglesias y a los que arrancaran mo-

13 Colección de cánones que constituyeron la base del derecho canónico moderno y fueron compilados por el monje camaldulense Graciano.

14 Fernando GONZÁLEZ DE SOCUEBA, Instrucción manual.., p. 91.

15 M. SÁNZ GONZÁLEZ, «El derecho de asilo. ¿Misericordia o justicia?», en Revista española de derecho canónico, 51 (1994), pp. 498-500.

16 M. SÁNZ GONZÁLEZ, «El derecho de asilo..., p. 501. 
jones ${ }^{17}$. Las Partidas añadían en esta lista a los defraudadores del fisco ${ }^{18}$. En ambos reglamentos se consideraba que «el sagrado» afectaba tanto a iglesias como a cementerios, entendiendo cementerio no sólo como campo santo, sino también como atrio, monasterio y terreno circundante ${ }^{19}$. Estas leyes continuaron con la tradición anterior de intercesión en los casos de siervos que se escapaban o deudores, debiendo ser entregados bajo juramento de sanidad de miembros y vida. En el terreno práctico Alfonso X luchó contra los obstáculos que pudiera presentarle esta costumbre, como en el caso ya mencionado de los deudores del fisco, llegándola a revocar en 1267 para la zona del Alto Guadalquivir, debido a graves problemas de orden público ${ }^{20}$.

La legislación eclesiástica castellana, comprendida en las Constituciones Sinodales propias de cada diócesis, impulsó el afianzamiento del derecho de asilo al establecer penas de excomunión o entredicho contra aquéllos que lo quebraran. Fueron los casos de Santiago en $1289^{21}$, Orense en el siglo XIV ${ }^{22}$ o León en $1303^{23}$. También se establecieron graves penas contra los clérigos que ayudaran a sacar a los recogidos (Ávila, 1481) ${ }^{24}$ o se especificaron casos especiales, como el del amparo que proporcionaba el Cuerpo de Cristo. En este último caso el derecho de asilo no habría de valer en las prisiones a los condenados porque, de lo contrario, eran enviados al patíbulo sin haber recibido los sacramentos (Segovia, 1325) ${ }^{25}$.

En el caso de Aragón los problemas se superaron en 1247, al crearse mediante fuero el Tribunal de Competencias, un tribunal civil que dilucidaba si debía concederse o no la inmunidad. La Iglesia aceptó esta disposición como si fuera un canon al haber contado en su elaboración con la participación del nuncio. En el reino de Valencia, Jaime I promulgó en 1272 una ley en virtud de la cual reducía los asilos a una sola iglesia en cada localidad, acabando con la enorme diversidad de lugares sagrados que ofrecían refugio a los delincuentes. Estas soluciones de la Corona de Aragón contrastan con la evolución que en los reinos de influencia castellana sufrió esta figura jurídica, llegando a convertirse en uno de los contenciosos más graves entre las jurisdicciones eclesiástica y civil durante toda la Edad Moderna.

\footnotetext{
17 Fuero Real, Título V ley VIII.

18 Siete Partidas, I Partida, Título XI, ley IV.

19 En Espéculo se extiende el derecho de asilo a la morada regia. pp. 85-86.

20 José Rodrígez MOLINA, «Alfonso X y la Iglesia Jiennense», en CEMYCYTH, 17 (1992),

21 Antonio García y GarCía (Dir.), Synodicom Hispanum, Madrid, Editorial Católica, 1981, Tomo I, pp. 117-125.

22 Ibidem*

${ }^{23}$ Ibidem, Tomo III, p. 263.

24 Ibidem, Tomo VI, p. 127.

25 Ibidem, Tomo VI, p. 305.

Mundo moderno

Hispania Sacra 55 (2003)
} 
En Navarra, el Fuero de Estella (1090), procedente del Fuero de Jaca y concedido a la mayoría de las localidades navarras durante el siglo XII, eximía del asilo a los ladrones manifiestos y a los traidores probados, reconociendo este derecho a iglesias y palacios ${ }^{26}$. El Fuero General de Navarra, compuesto a mediados del siglo XIII, añadió que el fiador podía sacar de iglesia o palacio al que le hizo fianza ${ }^{27}$.

\subsection{La desaparición del derecho de asilo civil.}

Es cierto que, en la mayoría de los casos, el derecho de asilo se refirió a la protección que proporcionaban las iglesias, sin embargo hay que subrayar que algunos fueros medievales, como el navarro, también reconocían este privilegio a lugares civiles como los palacios de infanzones. Aunque es posible que con el tiempo esta peculiaridad se convirtiera en un uso arcaico y bastante poco común, todavía en el siglo XVI nos encontramos con esta figura jurídica.

Quizá el caso más claro lo encontremos en un pleito sostenido entre el marqués de Falces y el señor de los palacios de Goñi y Peralta. Un día del mes de agosto de 1536 Martín y Pedro Sola, vecinos de Peralta (Navarra), hirieron al teniente de bayle. En lugar de dirigirse a la iglesia, como solía ser habitual, se refugiaron en el palacio de Miguel de Goñi y Peralta. Cuando la justicia y posteriormente el Marqués de Falces acudieron a extraer a los delincuentes de la casa, el palaciano se negó llegando a resistirse por la fuerza. A resultas de este incidente el Marqués de Falces interpuso un pleito en el que acusaba a Miguel de Goñi y Peralta de desacato a la autoridad, amparo de maleantes, injurias y otros abusos. El palaciano justificó su actuación basándose en el derecho foral que claramente reconocía el privilegio de inmunidad de los palacios ${ }^{28}$. Está

\footnotetext{
${ }^{26}$ Redacción. S. «174. Del malfaytor que se emparara en glesia o en palaçi d'infançón. Si algún malfaytor per defendrese intra en glesia o en palaci d'infançon, non deu estar trayt per força si doncx no es manifest layrón o traydor provat».

José Ma LACARRA, Ángel MARTín DuQue, Fueros de navarra. I. Fueros derivados de Jaca. 2. Pamplona, Pamplona, Diputación Foral de Navarra, 1975. p.402.

27 «81. De malfechor que deve ser emaparado en glesia o en palacio de ynfançón. Si algún malfechor en glesia o en palatio de ynfançón entrare non deve ser sacado si non fuere ladrón manifiesto o traydor provado, o si oviere seydo preso e ovierre pleyteado su remptión e dado fiador que todo fiador deve e puede sacar de glesia o de palatio ad aqueyll malfechor que l'echo fiador».

Juan F. UTRILla UTRILlA, El Fuero General de Navarra. Estudio y edición de las redacciones protosistemáticas (Series A y B), Pamplona, Gobierno de Navarra, 1987, Tomo II, Serie B, p. 84.

28 «segunt ley, fuero de este Reyno, mi dicho palacio y los que son de su calidad tienen privilegio para que del y de ellos no sean sacados los delinquentes y que en ellos se retraen y porque por ley tienen la dicha inmunidad si los ministros de justicia tentan de sacarlos hazen contra ley y en el dicho caso lizicita es la resistencia. lo otro porque yo en mi tiempo y mis antepasados en el suyo, conofme a 
argumentación fue rechazada por la acusación al dar a entender que se trataba de un uso antiguo que no se guardaba porque, de lo contrario, la seguridad del Reino se vería gravemente comprometida al quedar impunes los delitos ${ }^{29}$. A pesar de que el proceso quedó pendiente, el tribunal pareció dar la razón a la defensa, puesto que en la última parte del proceso lo único que trata de dilucidar es si existió un delito de injurias, proponiendo unas penas mucho más leves que las que corresponderían a delitos tan graves como los que se planteaban.

A partir de mediados del siglo XVI rara vez encontraremos referencias expresas a este derecho foral. Sin embargo, aunque en los procesos ante los Tribunales Reales se dejara de usar como argumento, los palacios y sus señores seguirán ofreciendo cierta protección no reconocida basada en la costumbre. A este respecto es muy ilustrativo el proceso que, en 1582, el fiscal interpuso contra el vizconde de Zolina por amparo de maleantes, resistencia a la autoridad y complicidad en la fuga de un preso. Un día que jugaba a pelota en la rúa Mayor de Sangüesa (Navarra) el vizconde junto con otros hidalgos de la villa, se enteró de cómo el teniente de almirante había entrado en su casa para prender a un famoso bandolero que allí recogía. En cuanto le comunicaron lo que sucedía en su palacio acudió con sus partidarios agrediendo al teniente de justicia, tratándolo de «bellaco y borracho» y diciéndole «si se abía de atreber a prender a nadie en su cassa $\rangle^{30}$. A diferencia del palaciano de Goñi, el vizconde de Zolina no hizo ninguna referencia al derecho foral que reconocía el derecho de inmunidad a los palacios, dando a entender que se trataba de una ley fuera de toda vigencia. Esta vez los tribunales fueron mucho más duros que en el caso anterior y después de guardar el vizconde un mes de prisión en la Fortaleza Vieja de Pamplona, tras pagar 1.000 ducados y pasar tres meses de arresto domiciliario en su casa de la capital, se le condenó a dos años de destierro y a pagar cuatrocientos ducados además de las costas del juicio ${ }^{31}$.

Los palacios no fueron los únicos lugares civiles que gozaron de inmunidad, aunque sí son los únicos que en cierta medida la llegaron a ejercer. En 1703 el rey Felipe V, a un petición del Regimiento de Pamplona, confirmó el «privilexio que los señores reyes mis anttezesores le conzedieron de ynmuni-

\footnotetext{
la dicha leye de tiempo ynmemorial a esta parte emos estado y estoy en esta posesión bescasi de entrar de la libertad e inmunidad resistiendo a quales quiere oficiales».

AGN, Tribunales Reales. Procesos, 85888 (1537), f. 217.

29 «si sabes que si tal pribilegio lo posesión o viese y se goardase que sería muy perjudicial e danoso para este reyno, e ocasionado para que muchas personas toama en atrebimiento a delinquir e delinquiese e hiziese muchos delitos e mas se seguiría desasosiego en las ciudad, villas y lugares de este reyno".

Ibidem, f. 23.

30 AGN, Tribunales Reales, Procesos, 98525 (1582), f. 37.

31 Ibidem, f. 164.
}

Mundo moderno

Hispania Sacra 55 (2003) 
dad local a la casa del Ainunttamientto de la dicha ciudad practicado ynconculsamentte astta aora y confirmado por mis reales proxenittores $\rangle^{32}$. Por la documentación consultada, este derecho parece tratarse de un privilegio puramente nominal, que nunca o casi nunca se ejerció.

\section{LA REGULACIÓN DEL ASILO ECLESIÁSTICO EN EL XVI: CONSTITUCIONES SINODALES Y APLICACIÓN DEL CONCILIO DE TRENTO}

La reforma religiosa que tuvo lugar en la España de fines del XV y principios del XVI, antes de la celebración del Concilio de Trento, trató de transformar la vida y las costumbres desterrando los antiguos usos medievales e impulsando un nuevo modelo de vida cristiano, a través de un mayor cuidado en los ritos y en los mandamientos de la Iglesia. Estos esfuerzos se plasmaron en las Constituciones Sinodales, en las que, para el caso de la inmunidad, se hizo gran hincapié en la búsqueda de la honestidad, el recato y el respeto, por parte del recogido, hacia el lugar sagrado que le proporcionaba asilo.

«Porque somos informados, que muchas personas, que cometen delictos porque temen ser pugnidos y castigados por la justicia seglar se acogen a las yglesias, y lugares sacros queriendo gozar de su immunidad están en ellas tan deshonestamente que Dios nuestro señor es muy deservido y sus sagrados templos profanados, y las personas ecclesiásticas reciven mucha turbación, quando celebran los officios divinos. Por ende desseando obviar los dichos inconvenientes S.S.A. estauymos que de aquí adelante los que se acogieren a los lugares sacros, estén en ellos honesta y recogidamente, y no jueguen en ninguna manera a juego alguno, ni tengan conversación con sus mugeres, ni con otras dentro de las yglesias, ni se pongan a las puertas de ellas, ni en los cimenterios a burlar, ni tañer vihuelas, ni otros géneros de instrumentos, ni usar otras conversaciones cocosas, o deshonestas. Antes esté muy recogidamente con mucha humildad y honestidad, como personas que han errado.

Otro sí mandamos que si algunos retraydos se salieren de las iglesias a hazer algunos enojos o cometen delicto alguno en la dicha iglesia o salieren de ella en qualquier manera por el mismo caso sean echados de la dicha iglesia o lugar sagrado, donde los tales retraýdos estuvieren. y mandamos a los curas y beneficiados y sacristanes y a todas la otras personas que tienen cargo de las dichas iglesias o hospitales, so pena de excomunión, que den aviso luego de ello a nuestro vicario general, para que sean echados fuera de la iglesia, como violadores de la honestidad de ella, y no los acojan en ella, ni en otra y porque muchas están

32 AGN, Tribunales Reales, Procesos, 18624 (1703), f. 3. 
en la iglesia tanto tiempo que paresce tenerla como por morada más que por refugio de sus personas. Mandamos que ninguno pueda estar en la iglesia, ni se acoja en ella por más tiempo de un mes sin liçencia de nuestro vicario general y juez eclesiástico y los clérigos entendiéndose contraviene en algo a lo mandado en esta constitución nos lo avisen so pena de un ducado, applicado, la mytad para la guerra que su magestad haze contra infieles durante la concessión de su sanctidad y la otra mytad para obras pías a nuestra disposición» ${ }^{33}$.

Este texto, aparentemente tan rico en detalles costumbristas, sobre los abusos que se cometían en lugares sagrados, se repite prácticamente igual, palabra por palabra, en todas las Constituciones Sinodales castellanas del siglo XVI, desde Sevilla en $1512^{34}$ hasta Badajoz en $1601^{35}$, extendiéndose a los lugares de influencia castellana, como México ${ }^{36}$ o Navarra. La única diferencia se encuentra en el plazo que se concede al refugiado para abandonar el lugar sagrado, que oscila entre los 8 días, en la mayoría de los casos, y el mes, tan sólo en el caso de Pamplona.

Los testimonios que nos hablan sobre la vida que llevaban los refugiados en las iglesias son realmente escasos, ya que normalmente el tema no interesaba a las causas que se llevaban a cabo. Sin embargo, los testimonios recogidos ilustran el poco éxito que tuvieron todas las medidas diocesanas sobre el período de permanencia y la compostura que debían mantener los asilados. Todavía en el XVII y en el XVIII nos encontramos con testimonios que nos hablan de los largos períodos de permanencia, así como de las adaptaciones que hacían los asilados para pasar mejor su estancia. Quizá el más significativo sea uno de 1604 cuando, a raíz de una fuerza realizada contra un hombre que llevaba tres meses en la iglesia, se describe el modo en que tenía su cama en la sacristía, que guardaba los alimentos en cajones de ornamentos y que hacía fuego en el coro $^{37}$. Este caso no dista mucho de los que Francia Lorenzo nos ofrece para la diócesis de Palencia ${ }^{38}$. Otros testimonios menos gráficos nos describen la nor-

33 Constituciones synodales del Obispado de Pamplona / Copiladas, hechas, y ordenadas por Don Bernardo de Rojas, y Sandoual, Obispo de Pamplona ... En la Synodo, que celebro en su Iglesia Cathedral, de la dicha ciudad, en el mes de Agosto, de M.D.XC. años, en Pamplona, por Thomas Porralis, 1591, pp. 125-126.

34 Juan TEJADA Y RAMIRO, Colección de cánones..., Tomo V, p. 96.

35 Antonio García Y García (Dir.), Synodicom Hispanum..., Tomo V, p. 79.

36 Juan TEJADA Y RAMIRo, Colección de cánones..., Tomo V, p. 141.

37 ADP, 250/13.

38 Nos describe cómo en 1626 en la Iglesia San Pedro de Astudillo permanecía un refugiado en un cubículo que se había preparado en la torre de la iglesia. p. 37. Todavía en un pleito de 1792 el tribunal hace las siguientes recomendaciones sobre el amparo de un asilado: «disponiendo sitio cómodo y proporcionado donde habite y se recoja, procurando, que, aunque sea dentro de la iglesia, esté apartado de lo más interior para evitar la más leve ofensa e irreverencia», p. 89.

Santiago Francia Lorenzo, Delincuentes. El derecho de asilo en Palencia, Palencia, Cálamo, 2001.

Mundo moderno

Hispania Sacra 55 (2003) 
malidad en la que vivían los refugiados en las iglesias. En Sesma (1672) los vecinos del pueblo sacaron a un hombre que había permanecido trece meses refugiado en la ermita de San Salvador ${ }^{39}$. En 1726 apresaron a un contrabandista que permanecía en la iglesia parroquial cuando salía a por un ascua para la pipa $^{40}$. En 1768 un hombre acusado de haber dado música de noche en Lodosa fue atrapado cuando tomaba el sol fuera de la iglesia parroquial ${ }^{41}$. Un clérigo que en 1650 había estado hasta seis meses recogido en la torre del obispo, acusado de estupro, testificó en un tribunal ${ }^{42}$.

El Concilio de Trento recogió el derecho de asilo y apeló a su defensa a través de la excomunión y el entredicho ${ }^{43}$. Durante el XVI el Papado adoptó una posición cada vez más dura en su defensa, siendo Gregorio XIV en 1591 el que interpretó este derecho de una manera más amplia, revocando disposiciones más permisivas hacia el quebranto de obispos anteriores ${ }^{44}$. Las bulas de Gregorio XIV fueron las que con mayor frecuencia se esgrimieron a la hora de justificar este derecho, a pesar de existir grandes dudas sobre su entrada en vigor en la mayoría de los reinos católicos. Para unificar criterios y animar a los obispos a defender este derecho, se creó la Congregación de Inmunidades y Controversias Jurisdiccionales.

La legislación civil española del XVI también se hizo eco de esta lucha contra los abusos y las violencias cometidos por los ministros de justicia, al extraer a los refugiados en sagrado. En las Cortes de Madrid de 1551 se propuso que los jueces pagaran «de su bolsa» los daños materiales causados en las iglesias, puertas, ventanas, incendios... ${ }^{45}$; en las de Toledo de 1559 también se pedía que los deudores fueran sacados sin daño ${ }^{46}$.

\section{LA INTERPRETACIÓN DE LA INMUNIDAD LOCAL EN LA EDAD MODERNA.}

A finales del siglo XV y principios del XVI la idea que se tenía sobre el derecho de inmunidad quedó totalmente perfilada, variando relativamente poco a lo largo de los tres siglos de la Edad Moderna. Remiro Goñi sistematizó per-

\footnotetext{
39 ADP, 891/15.

40 ADP, $1513 / 11$.

41 ADP, 2221/8.

42 ADP, 3248/16.

43 Concilio de Trento, Decreto sobre la Reforma, Cap. XX. «Recomiéndase a los Príncipes seculares la inmunidad, libertad, y otros derechos de la Iglesia».

44 AGN, Tribunales Reales, Archivo Secreto del Consejo, Tít. 8 continuación, fajo 1, n. 5.

45 Cortes de los antiguos reinos de León y Castilla, Madrid, Real Academia de la Historia, 1903, Tomo V, p. 515.

46 Ibidem, p. 828.
} 
fectamente esta nueva concepción en sus tratados De immunitate ecclesiarum y De Charitativo subsidio. Las ideas de este autor fueron difundidas gracias al famoso Manual de Confessores y Penitentes de Martín de Azpilcueta ${ }^{47}$, que basó sus capítulos sobre inmunidad en la obra de este «doctíssimo y no menos christiano, doctor don Remigio de Goñi, Arcediano mayor de Pamplona».

Goñi encontraba el fundamento de este derecho en dos razones: por un lado el privilegio que tenía la Iglesia de que nadie fuera sacado violentamente de ella. Debido a su carácter sagrado no podía admitir que ocurrieran luchas sangrientas, rapiñas o cualquier escena violenta en sus recintos. La segunda razón que confirmaba este derecho era la pertenencia a la jurisdicción eclesiástica de todos los territorios sagrados, por lo que todo reo que se refugiaba en ellos entraba automáticamente dentro de la potestad eclesiástica ${ }^{48}$.

Los procesos sobre inmunidad eclesiástica resueltos en los tribunales de la diócesis de Pamplona y depositados actualmente en su archivo, ilustran perfectamente esta cuestión. Un $70 \%$ de los procesos era promovido exclusivamente por el fiscal, mientras que la persona extraída tan sólo participaba en el $20 \%$ de los casos, acompañando, la mayoría de las veces, su queja a la del fiscal ${ }^{49}$. El fiscal exigía bajo pena de excomunión que el reo fuera devuelto a la iglesia de la que había sido extraído por fuerza. Frente a estas presiones, la justicia seglar cuestionaba que el reo hubiera sido apresado en lugar sagrado y trataba de incluir su delito entre los delitos exceptuados, es decir, aquellos que impedían el gozar de inmunidad. El fiscal buscaba siempre cualquier resquicio que justificara la falta del acusado, tratando de convertir delitos considerados como horribles y alevosos en susceptibles de gozar de la inmunidad ${ }^{50}$. En la mayoría de los casos la sentencia era favorable al reo, exigiendo su devolución al lugar sagrado del que había sido extraído o a cualquier otro que él eligiera. Hasta el siglo XVII este tipo de resolución supone el $71 \%$ de los procesos, mientras que

\footnotetext{
47 Martin AZPILCUETA, Manual de confessores y penite[n]tes: que clara y breuemente contiene la universal y particular decisión de quasi todas las dubdas que en las confessiones suelen occurrir delos [sic] peccados, absoluciones, restituciones, censuras \& irregularidades, compuesto antes por un religioso de la Orden de Sant Francisco... y despues visto y ... declarado ... por ... Martin de Azpilcueta Navarro ...; y agora ... reformado y acrescentado por el mesmo Doctor ..., Fue impresso en Medina del Campo, por Iohan Maria da Terranova y Iacobo de Liarcari en casa de Guillermo de Millis, 1555, pp 405-407.

48 T. GARCÍA BARBERENA, Un canonista español, el Doctor don Remiro Goñi (1481-1554), Pamplona, Pampilonenesia, 1947, p. 38.

49 José Luis Sales TIRAPU, Isidoro URSUA IrIGOYen, Catálogo del Archivo Diocesano de Pamplona: sección procesos, Pamplona, Gobierno de Navarra, 1988.

50 Según Palencia «el celo por la defensa de los derechos de las igleisas llevaba a pararse en nimiedades... que podían suponer una cierta provocación y, en consecuencia, disminuir la responsabilidad del reo apresado" y así poder gozar de inmunidad.

Santiago FRANCIA LORENZO, Delincuentes..., p. 191.
}

Mundo moderno

Hispania Sacra 55 (2003) 
en el XVIII se aprecia una reducción, llegando al 66\%, signo inequívoco del cambio de los tiempos ${ }^{51}$. Todo el esfuerzo que realizaba la justicia eclesiástica en estos procesos expresa claramente cómo lo que se dilucidaba no era tanto el derecho de las personas que se acogían en las iglesias, sino más bien un privilegio, una prerrogativa, un ámbito jurisdiccional propio de la Iglesia.

Nadie que tuviera derecho al acogimiento podía ser extraído de un lugar sagrado sin contar con su voluntad, aunque se recurriera al engaño, al miedo o se le obligara cortándole el suministro de comida, al igual que tampoco podía ser condenado a ningún tipo de pena corporal ${ }^{52}$. Un reo que escapaba de la justicia, una vez que alcanzaba lugar sagrado, no podía ser capturado. Igualmente, si a la hora de ser trasladado de un lugar a otro, los oficiales de justicia atravesaban un lugar sagrado, el reo podía pedir amparo ${ }^{53}$. Los que pretendían gozar de inmunidad trataban de acceder a ella, bastando incluso tocar los barrotes del cementerio mientras gritaban: «iIglesia, Iglesia!», «iIglesia me 1lamo!» o se esforzaban en reclamar testigos ${ }^{54}$.

Cuando se fallaba a favor del preso, y en contra de aquel que había permitido el quebrantamiento, el juez debía proveer las medidas necesarias para que el reo fuera conducido al lugar del cual había sido extraído y, en caso de no ser posible, a cualquier otro que también gozara de inmunidad ${ }^{55}$.

Las autoridades eclesiásticas tenían el deber y el derecho de proteger estas prerrogativas por medio de censuras y sanciones contra los infractores, siendo la más corriente la excomunión, que inhabilitaba para el desempeño de cargos

51 Sin embargo estas sentencias no siempre se llevaban a cabo y no son pocos los casos en los que el reo moría en la cárcel tras esperar durante meses o años a que se cumpliera la sentencia.

52 En 1700, en Segura (Guipúzcoa), una persona acusada de homicidio es sacada de la ermita en que se encontraba mediante engaño, al habérsele prometido que se le iba a mandar a una iglesia más grande y segura. La sentencia ordena la restitución del reo.

ADP, 1202/15.

53 En 1734, un reo que era trasladado, pasa por la Plazuela del Convento de San Francisco de Estella (Navarra), al darse cuenta de que podía ser sagrado pide acogerse, debiendo ser restituido.

ADP, 1804/8.

54 En 1705, un soldado mata al centinela de su cuartel en Palencia, seguidamente se dirige a la iglesia y allí se agarra a las aldabas de las puertas gritando «Iglesia me llamo».

Santiago FRANCIA LORENZO, Delincuentes..., p. 78.

En otro caso, un guarda de ganado entra en el cementerio de de la iglesia de Baquerín (Palencia) y agarra los postes del pórtico mientras grita «Iglesia me llamo», o «séame testigos, que me sacan de la Iglesia».

Santiago FrANCIA LORENZO, Delincuentes..., p. 81.

55 Los lugares elegidos eran iglesias fronterizas, desde donde en un momento propicio fuera posible huir, traspasar la frontera y eludir la justicia. Ejemplo de ello son: Roncesvalles en 1706 para un mercader francés refugiado por deudas (ADP 130/1), Valcarlos en 1767 para un húngaro apresado por robo (ADP 1972/9) o un castellano, reo de un homicidio, que es llevado en 1646 a una iglesia de Castilla. 
públicos ${ }^{56}$. Por otro lado, habían de velar por la seguridad y el bienestar del reo acogido entre sus muros y, en caso de que no tuviera con qué sustentarse, se debía acudir a la limosna ${ }^{57}$.

A través de los procesos judiciales puede verse cómo los clérigos defendían este derecho con todas sus fuerzas, llegando incluso a resistirse con violencia o arriesgándose a ser agredidos ${ }^{58}$. Por el contrario, cuando un religioso colaboraba con la justicia civil para sacar a un recogido de sagrado, era juzgado y sancionado, considerándose una falta muy grave ${ }^{59}$.

Los lugares privilegiados eran aquellos que habían sido eregidos con licencia eclesiástica superior. Si no cumplían esta condición, aunque fueran lugares dedicados al servicio de Dios, se les consideraba profanos.

Las iglesias también ofrecían protección en el territorio que las circundaba, 40 pasos en el caso de las iglesias mayores y 30 en el de las menores. Sin embargo, la mayoría de las iglesias, al estar en poblado, no ofrecían protección a sus alrededores ${ }^{60}$. Sólo la puerta y el pórtico ofrecían refugio en cualquiera de los casos. Las capillas y oratorios sólo proporcionaban inmunidad cuando habían sido levantadas con licencias eclesiásticas ${ }^{61}$.

Había ciertos casos en los que los autores no se ponían de acuerdo. Uno era el de las iglesias destruidas ${ }^{62}$. Parte de los canonistas pensaba que en lo que había que fijarse era en el grado de destrucción del templo. Sin embargo, Goñi opinaba que, a pesar de que estuviera destruido, seguía conservando sus derechos siempre que hubiera esperanza de que volviera a ser restaurado. Puede que se hubiera procedido al derribo o abandono de la iglesia a través de órdenes eclesiásticas superiores por lo que, en este caso, no ofrecería ninguna protección a los delincuentes. Tampoco ofrecía asilo en el caso de un completo e irreversible abandono. Respecto a las iglesias en entredicho, opinaba que seguían ofreciendo los mismo derechos de acogimiento ${ }^{63}$. A efectos de inmunidad eclesiástica, el cementerio funcionaba exactamente igual que una iglesia porque, según el canonista, coincidían en muchos puntos: tenían prohibidas las

\footnotetext{
56 Santiago Francia LORENZO, Delincuentes..., p. 232.

57 T. GARCÍA BARBERENA, Un canonista español..., p. 39.

58 En Sesma en 1605 el clérigo es vejado y violentado por el alcalde, llegando a ser desnudado, al oponerse a una extracción.

ADP, 424/2.

${ }^{59}$ En 1639 en Lerín, un clérigo es condenado por practicar unas costumbres que no obedecen a su condición, entre ellas las de colaborar con la justicia civil en la extracción de refugiados.

ADP, 442/12.

60 T. GARCÍA BARBERENA, Un canonista español..., p. 40.

${ }^{61}$ Ibidem, p. 41

62 Ibidem, p. 42.

${ }^{63}$ Ibidem, p. 43.

Mundo moderno

Hispania Sacra 55 (2003)
} 
ventas profanas, eran consagrados, profanados, violados, sujetos al entredicho... ${ }^{64}$ Los hospitales que habían sido construidos con licencia episcopal también contaban con este derecho ${ }^{65}$. y, En los monasterios, tanto la iglesia como las celdas eran consideradas sagradas ${ }^{66}$.

Había ciertos lugares y situaciones especiales que también proporcionaban inmunidad. Un delincuente se podía refugiar en el Cuerpo de Cristo, es decir, en un sacerdote que llevara la Eucaristía ${ }^{67}$, excluyéndose la posibilidad de hacerlo cuando, después de preso, recibía la Eucaristía ${ }^{68}$. También se decía que los cardenales poseían el privilegio de conceder inmunidad a los condenados que hallaran a su paso ${ }^{69}$.

Este derecho estaba sujeto a toda una serie de limitaciones, existiendo ciertas figuras delictivas que no se podían beneficiar del mismo. La razón la exponía muy bien Remiro Goñi: «La inmunidad de la Iglesia, no puede ser la impunidad de cualesquiera criminales, ni los, templos pueden convertirse, contra el dicho de Jesucristo, en cuevas de ladrones» ${ }^{70}$.

Estaban excluidos los ladrones públicos, es decir, aquellos que habían sido sorprendidos en flagrante delito, se contaba con pruebas suficientes para acusarlos, habían cometido hurtos notorios o confesos, asaltado caminos o provocado incendios. Tampoco se podían acoger aquéllos que habían cometido homi-

64 En 1605 la justicia civil trata de rechazar como lugar sagrado un cementerio en el que se había refugiado un vecino de Hernani acusado de asalto de caminos. La defensa afirma «No ser lugar sagrado como suelen hazer muchos regozijos y fiestas profanas y an sucedido muchas cuchilladas y efusión de mucha sangre sin que por esta caussa aya sido jamás biolada la dicha iglesia».

ADP, 173/7, f. 16.

65 En 1668, en Pamplona, un soldado mata a su mujer y se refugia en el Hospital General. La justicia civil argumenta que el crimen es horrendo y, de todas maneras, el Hospital General no tiene derecho a otorgar asilo. La causa queda pendiente, por lo que todo indica que se da la razón a la justicia civil.

ADP, 970/7.

66 T. GARCÍA BARBERENA, Un canonista español..., p. 41.

67 «El párroco de San Antolín acude a la llamada de que hay una persona moribunda, cuando llega, Juan de Barrida, carnicero y vecino de Palencia, se asió a la custodia del Santísimo que el doctor Pando tenía en sus manos y comenzó a pedir iglesia a voz en grito, significando que se acogía a sagrado y no le podían apresar».

Santiago FRANCIA LORENZO, Delincuentes..., p. 29

$68 \mathrm{El} 1$ de mayo de 1800 , cuando los presos condenados a muerte por haber robado en el santuario de San Miguel de Aralar oían misa, se abalanzaron sobre el oficiante y le arrebataron el cáliz y la ostia consagrada. El obispo prometió que trataría de amejorar la sentencia y así soltaron el cáliz. Uno de ellos confesó que había oído en Olorón que tres presos habían hecho lo mismo, eludiendo así la pena capital. Los jueces eclesiásticos decidieron no haber lugar al asilo o inmunidad eclesiástica.

Florencio IDOATE, Rincones de la Historia de Navarra, Pamplona, Gobierno de Navarra, *Tomo I, p. 302.

69 T. GARCÍA BARBERENA, Un canonista español..., p. 46.

70 Ibidem, p. 45. 
cidios alevosos y a traición. Los delitos contra Dios y su Iglesia o los de lesa majestad, tampoco contaban con este derecho. Finalmente, aquéllos que no estaban dentro del seno de la Iglesia, como los judíos, los paganos o los excomulgados, tampoco podían acogerse a este tipo de protección ${ }^{71}$. En teoría, todos estos delincuentes podían ser extraídos del templo, aunque se empleara la fuerza; sin embargo, como ya se ha demostrado, la justicia eclesiástica siempre interpretaba el derecho de asilo de una manera muy amplia, acogiendo a casi todos los que se refugiaban en las iglesias.

\section{LA INMUNIDAD: FUENTE DE CONFLICTOS IGLESIA-AUTORIDADES CIVILES.}

Posiblemente los mayores conflictos que se produjeron a lo largo de la Edad Moderna entre la jurisdicción civil y eclesiástica se debieron a disputas originadas por el derecho de inmunidad. Tan sólo cuestiones relacionadas con el protocolo adquirieron la gravedad de estas diferencias.

El derecho de asilo se trataba de un asunto de jurisdicción mixta, de materia espiritual y temporal ${ }^{72}$. Los intereses de las dos jurisdicciones se encontraban totalmente encontrados. Por un lado, se entorpecía la acción de la justicia, mientras que por otro, se atacaba un derecho considerado sagrado, inalienable a la Iglesia. Al mismo tiempo que la jurisdicción eclesiástica lo defendía a través de excomuniones y entredichos, la jurisdicción civil extrañaba a los clérigos y les embargaba temporalidades.

A fines del XVI y durante todo el XVII, a partir de las disposiciones de Gregorio XIV, la postura de la Iglesia se tornó especialmente dura, recibiendo una violenta oposición por parte de las autoridades civiles que aguzó aún más el problema. Ejemplo de ello son, entre otros, los conflictos que se produjeron en Granada, Alhucemas o Navarra.

En 1630 el provisor del obispado granadino fue extrañado a Portugal, debido a ciertas excomuniones interpuestas en defensa de un reo. En 1636, durante las fiestas del Corpus, el provisor declaró el entredicho a toda la ciudad por razones idénticas. En 1645, ante el temor a las censuras eclesiásticas y a que se pudiera producir un tumulto, un preso fue llevado muerto a la horca en plena noche, antes de que transcurrieran los tres días perceptivos para que se produjera el ajusticiamiento ${ }^{73}$.

\footnotetext{
71 Ibidem, pp. 46-51.

72 R. OLAECHEA, «Anotaciones sobre la inmunidad local..., pp. 299-308.

73 Pedro GAN GIMÉNEZ, «En torno al Corpus granadino del siglo XVII», en Chronica Nova, 17 (1989), p. 100.
}

Mundo moderno

Hispania Sacra 55 (2003) 
Otro ejemplo válido puede ser el del presidio de Alhucemas, en el que esta cuestión enrareció gravemente las relaciones entre la iglesia de Alhucemas y el gobernador de la plaza ${ }^{74}$.

Sin embargo, Navarra es sin duda uno de los lugares en los que este conflicto entrañó mayor gravedad ya que, a la problemática general del derecho de asilo, se le unía la disputa por saber a qué jurisdicción correspondía su administración. Parece ser que durante la mayor parte del siglo XVI los tribunales reales del reino, al igual que se hacía en Aragón, tuvieron la competencia de dilucidar si los reos podían disfrutar de este derecho. Esta posición es corroborada por más de 100 procesos conservados del Consejo Real de Navarra, máximo tribunal del reino, en los que, de manera unilateral y a petición del interesado, se concede o se deniega el derecho de asilo. Durante el obispado de Don Bernardo de Rojas y Sandoval, a fines del XVI, parece ser que por influencia castellana, la Iglesia consideró este asunto como una competencia propia y empezó a actuar contundentemente en cuanto se cometía un quebranto del derecho de inmunidad. Frente a los cuatro procesos conservados en el Archivo Diocesano de Pamplona (A.D.P.) anteriores a 1600, sólo en ese mismo año se producen cuatro pleitos. Un memorial de fines del XVII elaborado por el Consejo Real explica así lo ocurrido:

«Un informe original hecho por el regente y Consejo de Navarra, su fecha de 26 de septiembre de 1595, en virtud de dos cédulas de la Cámara, sus fechas en 30 de Octubre de 1589 y en 9 de Octubre de 1591 . Sobre diferentes puntos de competencias de jurisdicción entre el Consejo y los alcaldes de Corte, representado estos en quanto a el punto del conocimiento de las causas mixti fori y de inmunidad eclesiástica contra legos, avían conocido siembre privativamente en todo el reyno y, queriendo los oficiales y vicarios generales entrometerse en el conocimiento de los delitos, los avían inhibido y mandado al dicho vicario y a su notario embiasse los autos a la Corte, y que hasta que se viessen no hiziessen novedad y, en caso de no obedecer, avían proveído auto con pena de temporalidades, y los iuezes avían cumplido los mandatos, pertenecciéndoles el conocimiento en primera instancia a la Corte y al Consejo en grado de suplicación privativamente, y que esta avía sido la observancia en aquel reyno muy assentada, hasta que el obispo don Bernardo de Roxas y Sandoval y su vicario se avían entrometido en el conocimiento de algunos casos de los referidos y excomulgado a aquel tribunal, con mucha nota, sin guardar el respeto y buena correspondencia que sus antecessores y por no cumplir el mandato de la Corte en embiar los autos, diziendo que la Corte no podía proceder contra él.... ${ }^{75}$.

Durante el siglo XVII ambas jurisdicciones administraron este derecho, entorpeciéndose mutuamente. Todas la acciones emprendidas por la autoridad civil

\footnotetext{
74 Antonio CARMONA PORTILLO, «Enfrentamiento Iglesia-Estado en África española. El derecho de asilo en el presidio de las Alhucemas en los siglos XVIII y XIX», en Isla de Arriarán. Revista cultural y cientifica, 2000, pp. 99-107.

75 AGN, Tribunales Reales, Archivo Secreto del Consejo, Tít. 8 continuación, fajo 1, n. ${ }^{a}$ 7, f. 1.
} 
fueron contestadas con amenazas de censuras eclesiásticas, convirtiéndose todos los pleitos en continuas disputas por dilucidar a quién correspondía esta competencia. La jurisdicción civil argumentaba costumbre inmemorial del reino:

«En semejantes casos el conocimiento de si el delinquente a de gozar o no de la inmunidad eclesiástica es dado a los dichos señores alcaldes de Corte, los quales siempre que se a offresçido an conoscido de ello y están en estta costtumbre y posesión de tiempo ynmemorial a esta parte quietta y paçífficamentte a bistta ciençia y ttolerancia de los ordinarios de este obispado» ${ }^{76}$.

La jurisdicción eclesiástica, en cambio, se apoyaba en cánones, constituciones sinodales y bulas pontificias, especialmente las recientemente pronunciadas por Gregorio XIV:

«...si pareçiesse en este tiempo algunas sentencias declaradas en fabor de la Corte serian sin sabiduría y contradiçión del juez ecclesiastico... lo otro, el dicho motu propio quita los privilegios a los que tenían para sacar de la yglesia sin authoridad del juez ecclesiástico a las personas que conforme a derecho no podían gozar de inmunidad ecclesiástica y assí manda que aún en estos casos que no debe gozar no lo aya de sacar el juez lego sino el obispo o su vicario general y él lo aya de entregar al juez secular de manera que si esto es así y en el se derogan lo privilegios y los reduçe a los términos de derecho común. Y en casos que no se puede gozar de inmunidad ecclesiástica con quanta más razón se debe guardar lo en él contenido por la dicha Corte que ni tiene privilegio ni costumbre inmemorial» ${ }^{77}$.

Esta cuestión no llega a resolverse en ningún momento del siglo, por lo que las relaciones entre ambas jurisdicciones llegaron a enrarecerse gravemente. En 1638 el auditor de guerra del reino acusó al fiscal eclesiástico del obispado de Pamplona de apropiarse de esta competencia. Sin embargo, la condena fue absolutoria. Las Cortes de Navarra expresaron su preocupación por la difícil situación por la que atravesaban los alcaldes, que debían obedecer a dos jurisdicciones, que reclamaban lo contrario bajo amenazas de excomunión o castigos. Así, en en 1632 afirmaban: «...los alcaldes ordinarios sacan a los deliquentes de las yglessias y los remiten a la Corte y el juez eclesiástico procede con çensuras contra el tal alcalde. Y, si no los sacan, la corte los castiga a los alcaldes. De manera que de la una y otra parte se les hacen vexaciones. y, haviéndose ablado en esta raçón muy largo, se acordó, de conformidad, que se haga pidimiento que a los alcaldes ordinarios no se les haga vexación alguna y se provea del devido remedio ${ }^{78}$.

76 AGN, Tribunales Reales, Procesos, 100546 (1608)

77 AGN, Tribunales Reales. Procesos, 29188 (1594), f. 15.

78 Luis Javier ForTún PÉREZ DE CRIRIZA (ed.), Actas de las Cortes de Navarra (1539-1829), Libro 2 (1611-1642), Pamplona, Parlamento de Navarra, 1991, p. 257.

Mundo moderno

Hispania Sacra 55 (2003) 
La situación estalla en 1659 , cuando el alcalde ordinario de la villa de Lumbier extrae y conduce a las cárceles reales de Pamplona a Juan de Echarri y Juan Ruiz por la muerte de Miguel de Santesteban. Ante las resistencias a devolverlo a sagrado, el vicario general fulminó la excomunión y lanzó el entredicho ${ }^{79}$. Obispo y vicario general permanecieron en San Sebastián, quedándose al cargo de la diócesis Enrique de Urrués y Cruzat, canónigo y oficial principal. La Corte procedió a ocuparle las temporalidades halladas en su casa, por lo que también se dirigió a San Sebastián. El entredicho se mantuvo durante siete meses, hasta que mediaron Luis de Haro y José González, enviados por Felipe IV para negociar la Paz de los Pirineos. El Consejo Real cedió y devolvió los presos a sagrado ante la esperanza de que en Madrid se formara un Tribunal de Competencia, que decidiera a quién correspondía la jurisdicción. A pesar de toda la documentación mandada por ambas jurisdicciones, no se decidió nada, por lo que los problemas continuaron ${ }^{80}$.

El episodio se repite en 1693, cuando Diego Larrea, vecino de Falces, mata a Miguel de La Torre, regidor de la villa. El alcalde extrae al reo con violencia y lo manda a las cárceles reales de Pamplona. Mientras el virrey manda que se dé libertad al preso, la Corte declara que es ella la única que tiene jurisdicción. El vicario general excomulga a los alcaldes, mientras que éstos apresan a la persona que les comunica las censuras ${ }^{81}$. Cuando el virrey consigue que la situación se calme el preso reclama ante la Corte su libertad, por lo que el tribunal eclesiástico considera, una vez más, vulnerada su jurisdicción ${ }^{82}$. Como la vez anterior se manda a Madrid gran cantidad de documentos y se elaboran sendos memoriales ${ }^{83}$.

\footnotetext{
79 AGN, Tribunales Reales, Archivo Secreto del Consejo, Tít. 8, fajo 1, na . 49, v. 9.

80 José GoÑI GazTAMBIDE, Historia de los Obispos de Pamplona, Pamplona, EunSa y Príncipe de Viana, 1985, Tomo VI, p. 266.

81 AGN, Tribunales Reales, Archivo Secreto del Consejo, Tít. 8 continuación, fajo 1, nº 7, f. 2.

82 José GoÑI GAZTAMBIDE, Historia de los Obispos..., Tomo VI, pp. 450-454

83 «Memorial ajustado de los autos y procedimientos hechos por la Corte Mayor y Consejo de Navarra y por el provisor y vicario general de aquel obispado, y advocación que de ellos hizo el señor obispo de Pamplona y sentencia que dio contra los ministros del Consejo, y Corte Mayor sobre la diferencia que se ha movido en el conocimiento de la causa de inmunidad de Don Diego de Larrea, que fue extraído de la Iglesia de la villa de Falces, y está preso en las cárceles reales de la ciudad de Pamplona; y lo que passó sobbre la prisión y soltura de Francisco de Echalezu, secretario, notario de la Audiencia Eclesiástica, por aver ido a notificar unas letras del provisor y de los exemplares que se han remitido por el consejo y Corte Mayor de Navarra, en razón del conocimiento de la inmunidad de los reos extraídos de la iglesia y ocupados en las cárceles reales, y de los decretos de la Cámara, dando providencia a esta materia; la qual por decreto de su magestad de once de este presente mes de dizembre se ha mandado ver en el consejo pleno, y que se le consulte por él lo que se le ofreciere y pareciere, cuyo decreto se pone a la letra».

AGN, Tribunales Reales, Archivo Secreto del Consejo, Tít. 8 continuación, fajo 1, 7.
} 
Tras dos años, el Rey declara: «estoy persuadido a que en esse reyno está la jurisdicción $\mathrm{R}$. en posesión de conozer de la ynmunidad eclesiástica local, todavía porque deseo atender mucho a las cosas de la Yglesia y en conformidad de lo que manifesté a mi Consejo de Castilla en decretto de primero de deziembre del año próximo pasado con motivo de la dependencia del obispo de Pamplona açerca de que mi ánimo siempre a sido y es atender más y primero a la inmunidad eclesiástica que a mis propias regalías por decretto señalado de mi real mano de diecisiete del corriente he benido en ceder de la que me pertenece en esse reyno de que mis ministros conozcan de la inmunidad eclesiástica local y mando que en adelante se practique en esse reyno esta especie de conocimiento en la forma que se practica en los reynos de Castilla» ${ }^{84}$.

La Diputación del reino expresa su oposición, puesto que el rey «tiene jurado la observanzia de los fueros y leyes, privilexios, livertades, usos, estilos y costumbres deste reyno y de amexorarlos y no apeorarlos y que no los interpretará sino en utilidad y beneficio del reino», siendo «la costumbre y possesión de conozer vuestros Tribunales Reales deste reino de la ynmunidad» ${ }^{85}$.

Finalmente las Cortes de Corella de 1695 , en su ley 21 , ceden ante los deseos del rey, legislando «que corra el conocimiento de la inmunidad en los casos de extracción de reos de la iglesia por los tribunales eclesiásticos y sagrados del reino y no por seculares, salvado los recursos de fuerza y violencia» para que «se eviten las causas de donde se originan estas disensiones y competencias de jurisdición» y los «riesgos a que semejantes casos se exponen los pueblos y turbaciones de la quietud pública y serenidad de las conciencias» ${ }^{86}$.

A partir de este momento las relaciones entre ambos tribunales van a ser mucho más armónicas. Mientras el Tribunal Diocesano actúa legítimamente, los Tribunales Reales tan sólo se ocupan de los recursos de fuerza.

En 1742 la situación vuelve a empeorar, aunque esta vez el motivo ya no es la lucha por comprender esta jurisdicción. Fermín de Aguirre es extraído a la fuerza del convento de capuchinos extramuros de Pamplona, acusado de participar en una riña en la que se produjeron dos muertes. El presbítero que debía comunicar al Consejo las censuras del provisor es gravemente ofendido. Las censuras no son acatadas por los miembros del Consejo, que continúan con su actividad habitual ${ }^{87}$. Ante el peligro de un alboroto en apoyo al obispo, el virrey y el Consejo mandan cerrar las puertas de la ciudad prohibiendo la entrada

\footnotetext{
${ }^{84}$ AGN, Tribunales Reales, Procesos, 91233 (1695), f. 1.

85 Ibidem, f. 8.

86 Novissima Recopilción de las Leyes del Reino de Navarra hechas en sus cortes generales desde el año de 1512 hasta el de 1716 inclusive, Edición realizada conforme a la obra de D. Joaquín de Elizondo año 1735, Tomo II, Pamplona, Editorial Aranzadi, 1964, p. 629.

87 ADP, 2126/1.

Mundo moderno

Hispania Sacra 55 (2003)
} 
o salida de clérigos. Todas las amenazas de excomunión son interceptadas. El provisor es extrañado y llevado a la frontera con Francia junto con cinco clérigos. El obispo lanza el entredicho a todas las iglesias de Pamplona y arrabales, su palacio es violado y a él se le condena a temporalidades y destierro, aunque el pueblo, congregado en la plaza del palacio episcopal, evita su repatriación. Ante el curso que estaban tomando los acontecimientos el virrey llega a un acuerdo en virtud del cual se retirarían las condenas a todos los clérigos ${ }^{88}$. Sin embargo, cuando parecía que se había llegado a la normalidad, se reciben unas cédulas reales que mantienen el destierro del vicario general y amonestan gravemente al obispo, dando la razón a la justicia civil ${ }^{89}$. Este episodio se enmarca dentro de la política regalista que los Borbones aplicaron en todos sus dominios, opuesta a los privilegios de la Iglesia, y que poco tenía que ver con los conflictos anteriores.

Sin embargo, la inmunidad no sólo es cosa de dos (las jurisdicciones civil y eclesiástica); sin duda una de las claves que permitió su pervivencia a lo largo de la Edad Moderna fue su aceptación y su defensa por parte del pueblo. González Socueba alertaba, avanzado el siglo XVIII, de los peligros que suponía el actuar con violencia en la extracción de refugiados: «Yo hallo graves inconvenientes, en que no condescendiendo el eclesiástico a la entrega del reo y conducirle a sus cárceles, o a las reales, se empeñe el juez seglar en sacarle violentamente, pues aún dado el caso, de que es eclesiástico se esté passivo, sin hacer contradicción con armas, como estos lances regularmente son notorios, e irremediablemente concurre mucho vulgo a ellos, con sólo oir que dice el eclesiástico, que no debe ser extrahído el reo, cree la torpeza vulgar que es punto de religión y desacato a la Iglesia extraher el reo contra el dictamen del vicario o juez eclesiástico y suelen originarse tumultos y alborotos...». A pesar de lo que afirma Socueba, la razón de esta defensa no se encuentra en la torpeza vulgar que sufre el pueblo, sino más bien en la defensa de unos intereses propios, ya que «aseguraba protección contra las arbitrariedades de una justicia considerada del lado de los poderosos ${ }^{90}$ y podía constituir un buen recurso ante la comisión de futuros delitos, de los que nadie se encontraba a salvo.

88 José GoÑ GaZTAMBIDE, Historia de los Obispos..., Tomo VI, pp. 420-428.

89 «Autos y decisión Rl. sobre la competencia ocurrida entre los señores virrey, conde de Maceda, regente y Consejo de este reino con el Sr. obispo de esta ciudad de Pamplona Don Gaspar de Miranda y Argaiz, y su provisor Don Miguel Ygnacio de Luquin, acerca del modo en que había de ser restituído a sagrado Mguel Fermín de Aguirre, preso en las cárceles reales, acusado de dos homicidios».

AGN, Tribunales Reales, Archivo Secreto del Consejo, Tít. 9 continuación, Fajo 1, 1.

90 Antonio Morgado García, Derecho de asilo..., p. 45 


\section{CRISIS DE LA INMUNIDAD LOCAL.}

\subsection{Ofensiva legislativa.}

Frente a la actitud violenta que caracterizó a los ministros de justicia en el XVII, durante el XVIII se recurrió a argumentos judiciales, siguiendo los procedimientos legales para extraer a los delincuentes ${ }^{91}$. En el XVII los enfrentamientos entre ambas jurisdicciones fueron muy graves. La justicia seglar solía emplear violencia en la extracción de presos, siendo respondida contundentemente con excomuniones. Sin embargo, en el XVIII, la justicia secular tuvo mayor cuidado, ya que era consciente de que esta clase de conflictos podía provocar tumultos y confiaba cada vez más en unas leyes que apoyaban su labor más claramente ${ }^{92}$. Al mismo tiempo, la justicia eclesiástica apenas recurría a prácticas como la excomunión, que comenzaban a ser consideradas arcaicas ${ }^{93}$.

Una continua actividad diplomática de permanente negociación con la Santa Sede reclamando una reducción cada vez mayor del derecho de asilo, obtuvo como fruto una auténtica ofensiva legislativa que recortó irremediablemente la inmunidad local. Las bulas, los breves y los concordatos de esta época terminaron por anular el derecho de asilo. Al mismo tiempo, las autoridades eclesiásticas de la península tampoco defendieron el derecho de asilo con la dureza de las excomuniones generalizadas que caracterizaron al siglo anterior.

Esta nueva situación se vio propiciada por la continua presión que ejercieron los partidarios del regalismo a lo largo de todo el siglo. En Navarra, en 1701 , tan sólo seis años después de que le fuera reconocido a la jurisdicción eclesiástica el conocimiento exclusivo de las causas de inmunidad, aparece un memorial pidiendo recortes en el procedimiento comúnmente empleado. En este caso se proponía que los reos fueran presos y custodiados por la justicia seglar hasta que se discerniera su derecho a gozar de sagrado ${ }^{94}$. Quizá la crítica

\footnotetext{
91 Ibidem, p. 41

92 Este aspecto está muy bien reflejado en los consejos que Socueba ofrece a los ministros de justicia, para extraer a los reos de delitos exceptuados de las iglesias sin violencias.

«...Jamás he requerido al juez eclesiástico, diciéndole que de mi authoridad extraheré al reo, sino haciéndole ver que él mismo debe extraherle y entregarle en mis cárceles. Por esto le he hecho presente que el reo está a la vista dentro de su iglesia. Que ha cometido delito exceptuado y de ello ay pruebas suficientes, que le he hecho ver, y que en estos términos, en conformidad de la bula...es de obligación del dicho juez eclesiástico extraherlo y ponerlo en la cárcel protextándole de lo contrario, que será responsable a su magestad de la fuga del reo y de otras qualesquiera malas resultas, ofreciéndole el auxilio de tropa y ministros que necessite para en caso de que el reo se ressista al precepto del juez eclesiástico a salir de la iglesia...». Fernando GONZÁLEZ DE SOCUEBA, Instrucción manual.., p. 292.

93 Antonio MoRgado García, Derecho de asilo..., pp. 36-41.

${ }^{94}$ AGN, Reino, Negocios Eclesiásticos, Leg. 3, Carp. 65.
}

Mundo moderno

Hispania Sacra 55 (2003) 
más conocida sea la de Melchor Macanaz, fiscal del Consejo de Castilla, a quien juzgó por ello la Inquisición sin conocimiento del rey. Este asunto propició un duro pulso entre el rey y la Inquisición que duró hasta que el monarca capituló en $1721^{95}$. El propio libro de Socueba se enmarca dentro de estos intentos por parte de los regalistas de reducir, e incluso anular, el derecho de inmunidad. La mayoría de ellos exponía como modélicos los sistemas de Aragón y Valencia, en donde los asilos se limitaban a unas pocas iglesias, en el caso de Valencia, y eran los tribunales civiles los que decidían sobre si debían gozarlos o no ${ }^{96}$.

En el XVIII dentro de la lucha contra la deserción se combatió una de sus principales vías de escape, la inmunidad del sagrado. En 1715 se eximió del fuero militar a todos los soldados que se acogían a sagrado, pudiendo así ser perseguidos por las justicias ordinarias cuando salían de sus refugios ${ }^{97}$. Como Alberto Angulo pone de manifiesto, otra de las preocupaciones que va a llevar al Estado a tomar una actitud cada vez más dura frente al asilo va a ser el problema del contrabando. Los contrabandistas se amparaban en las iglesias, donde a menudo guardaban sus cargamentos, protegidos también, en ocasiones, por su condición de clérigos ${ }^{98}$.

Dentro del pulso sostenido entre la Iglesia y el Estado absolutista, el Concordato de 1737 supuso un punto de inflexión que inició el camino para la conversión de este derecho en una figura casi testimonial. En el Concordato se reiteró la no protección de salteadores o asesinos de caminos, incluso en el caso de un simple insulto, siempre que se sucediera muerte o mutilación. Tampoco comprendió a los reos de lesa majestad ni a los que se refugiaban en las llamadas «iglesias frías», es decir, aquellas en las que no se celebra misa ${ }^{99}$. Los artículos 2, 3, y 4 del Concordato, concernientes a inmunidad local, fueron mandados cumplir por Felipe V el 7 de diciembre de 1737100. Este Concordato defraudó las amplias expectativas que se habían creado dentro de los sectores regalistas, ya que sólo ratificaba lo que estaba mandado en otras legislaciones de la Iglesia ${ }^{101}$. Sin embargo, anteriormente estas reglas eran interpretadas de una manera muy laxa dando refugio prácticamente a todo tipo de delitos, incluso a los claramente exceptuados. Fue a partir de este momento cuando los casos de inmunidad local empezaron a ser examinados de un modo mucho más estricto.

\footnotetext{
95 R. OLAECHEA, «Anotaciones sobre la inmunidad local..., p. 326.

96 Juan TejadA Y RAmiro, Colección de cánones..., Tomo VII, p. 274.

97 AGN, Tribunales Reales, Archivo Secreto del Consejo, Tit. 9, fajo 1, 64.

98 Alberto ANGULO MORALES, «Kontrabandisten aurkako neurriak XVIII. mendeko Euskal Herrian: leku sakratuen desagerpena», en Uztaro, 21 (1997), pp. 45-67.

99 Juan TEJADA Y RAMIRO, Colección de cánones..., Tomo VII, p. 101.

100 AGN, Tribunales Reales, Archivo Secreto del Consejo, Tit. 8, fajo 1, 80

101 Juan TEJADA Y RAMIRO, Colección de cánones..., Tomo VII, p. 115.
} 
En 1741 un breve, excluyó de la inmunidad a los que cometían homicidio deliberado ${ }^{102}$.

En 1749 se dio un nuevo paso por parte del Estado dentro de los intentos de anular la inmunidad local. Aquellas personas que se refugiaban en la iglesia y habían cometido delitos por los que sí podían gozar de inmunidad, debían ser conducidas a «gozar» de sagrado a las iglesias de los presidios africanos ${ }^{103}$. Ejemplo de la aplicación de esta ley es el caso de tres vecinos del valle de Yerri acusados de bandidos y que en 1765 se refugian en la iglesia parroquial de Echarri Aranaz. Cuando la sentencia les «concede» gozar del refugio en sagrado en la iglesia del presidió de Orán, ellos se ven obligados a renunciar.

Como muy bien explica Socueba, «en estos términos exercitado el uso de los asylos se halla no sólo moderado, sino casi abolido, porque siendo inútil el recurso a ellos a los que no los gozan en modo alguno es a los demás perjudicial la inmunidad por delitos más ligeros, porque no pudiendo tener por ellos pena grave, lo es y muy, gozar el refugio en una iglesia de los presidios sin limitación de tiempo y con el riesgo de caer en manos de la justicia, que havrá de castigarles, como si no huvieran estado refugiados ${ }^{104} \gg$.

En 1765 Carlos III promovió una Real Pragmática en la que se instaba a la justicia a extraer a los refugiados en las iglesias.

La última disposición que convirtió esta figura jurídica en una reliquia del pasado meramente testimonial fue el Breve de Reducción de Asilos de Clemente XIV, conseguido tras una dura y larga negociación entre el Papa y el futuro conde de Floridablanca, embajador de Carlos III. El breve Ea semper fuit del 12 de septiembre de 1772 obligó a señalar uno o dos lugares de asilo, no habiendo ninguna otra iglesia inmune. En las iglesias no señaladas se debía extraer a cualquier delincuente sin problemas, mientras que en las otras se debía proceder a su extracción cuando su delito fuese de los exceptuados, debiéndolo poner antes en conocimiento del vicario o del representante competente de la autoridad eclesiástica, evitando así toda profanación.

En la diócesis de Pamplona el Breve de Reducción de Asilos se puso en práctica a través de un Edicto del obispo Don Juan Lorenzo de Irigoyen y Dutari, del seis de marzo de $1773^{105}$, que fue comunicado ese mismo año a las diferentes parroquias de la diócesis ${ }^{106}$.

\footnotetext{
102 AGN, Tribunales Reales, Archivo Secreto del Consejo, Tit. 8 continuación, fajo 2, 9.

103 AGN, Tribunales Reales, Archivo Secreto del Consejo, Tit. 8, fajo 2, 17.

104 Fernando GONZÁLEZ DE SOCUEBA, Instrucción manual.., p. 243.

105 AGN, Tribunales Reales, Archivo Secreto del Consejo, Tit. 8 continuación, fajo 3, 1.

106 Archivo Municipal de Barásoain, Leg. 1. Archivo Municipal de los Arcos, Caja 8.
} 
6.2. Un caso concreto: la práctica de la inmunidad en la Navarra del setecientos.

La cantidad y frecuencia de pleitos de inmunidad en el Archivo Diocesano de Pamplona responde al desarrollo legislativo que este fenómeno sufrió a lo largo de la Edad Moderna. La diócesis de Pamplona comprendía la mayor parte de Guipúzcoa, así como una zona de Navarra. Respecto a la Provincia de Guipúzcoa se siguió la legislación castellana, no existiendo ninguna duda sobre quién debía de administrar este derecho; sin embargo en el reino de Navarra, como ya se ha señalado anteriormente, fue a partir del obispado de Bernardo de Rojas y Sandoval, en la década de 1590, cuando la jurisdicción eclesiástica decidió asumir esta competencia. El A.D.P. conserva 116 procesos del siglo XVII, teniendo en cuenta que gran número de estas cuestiones se solucionaban en los tribunales civiles, de los que todavía no se pueden obtener datos exactos, debido al incompleto proceso de informatización en el que se encuentra su documentación. En 1695 el rey concede a la justicia eclesiástica la competencia exclusiva sobre este problema. Debido a esta exclusividad la cantidad de procesos crecerá respecto al siglo anterior hasta que, a partir del breve pontificio Ea semper fuit de 12 de septiembre de 1772, el derecho de asilo quede completamente anulado, llegando prácticamente desaparecer. Del siglo XVIII se cuenta con 102 procesos, de los cuales tan sólo tres son posteriores la publicación del Breve.

La fuente consultada, los procesos judiciales depositados en el Archivo Diocesano de Pamplona, presenta una carencia que puede tergiversar cualquier conclusión que se pueda obtener sobre la criminalidad en esta época. Los procesos judiciales conservados no tratan sobre todos los delincuentes recogidos en terrenos sagrados, sino sólo sobre aquellos casos especialmente problemáticos en los que la justicia civil llegó a intervenir. No es extraño que otros tipos de fuentes de la época ofrezcan abundantes referencias sobre la figura del recogido, un delincuente que no era molestado por nadie mientras permaneciera en terreno sagrado. Si se tiene en cuenta esta premisa, lo que obtendremos después de estudiar los delitos cometidos por los refugiados no es tanto un mapa de la criminalidad en esta época, como trata de ver Morgado García ${ }^{107}$, sino más bien una visión de aquellos delitos que por diferentes factores interesaban en mayor medida a la justicia ${ }^{108}$. Efectivamente, podían responder a un

107 Antonio MORGADO GARCÍA, Derecho de asilo..., pp. 87-144

108 Iñaki BAZÁN, «Criminalidad y violencia. La historia social de las mentalidades y la criminalidad», en Carlos BARros (ed.), Historia a Debate, Tomo II, La Coruña, 1995, pp. 85-101; Carlos MAIZA OZCOIDI, «Utilización de fuentes y cuestiones metodológicas respecto a un estudio de la historia de las mentalidades: el concepto del honor en la sociedad de los siglos modernos», en Gerónimo Uztariz, 
esquema delictivo de gravedad casi objetiva, como en el caso de los homicidios; sin embargo también podían ser perseguidos porque chocaban contra esquemas nuevos de valores, como en el caso del contrabando o la deserción del ejército, delitos que para el Estado centralizado borbónico cobraron una gran importancia, a pesar de que para la inmensa mayoría de la población pudieran tratarse de actividades legítimas.

En el A.D.P. se puede encontrar una significativa variación a lo largo del tiempo en los delitos cometidos por los refugiados en las iglesias. Durante el siglo XVII prácticamente la mitad de los delitos está relacionada con actos violentos, un $27 \%$ por homicidio y un $21 \%$ por heridas, mientras que en el siglo XVIII este tipo de delitos apenas supone un $20 \%$ del total, un $13 \%$ por homicidio y un $8 \%$ por heridas. Frente a esta reducción de los delitos violentos, los delitos relacionados con agresiones contra el poder del Estado aumentan espectacularmente, de un $21 \%$ a un $46 \%$. Entre estos delitos encontramos el de contrabando, que en el XVI apenas supone un $5 \%$ y en el XVIII alcanza el $14 \%$ del total, y sobre todo la deserción, que aumenta de un $2 \%$ a un $15 \%$. Otros delitos que pertenecerían a este apartado (fugas, asalto de caminos, desórdenes públicos, lesa majestad) se mantendrían estables a lo largo de los tres siglos dentro de cifras que oscilan entre un $2 \%$ y un $5 \%$. Los delitos calificados de económicos (robo, deudas y falsificación de moneda) aumentan también considerablemente, del 5 al 13\%, debido a una mayor importancia de los delitos relacionados con el robo.

Del análisis de estos datos se podría desprender la teoría tantas veces defendida de la evolución de un modelo de criminalidad medieval que debido al concepto de honor provocaba una gran violencia interpersonal, a un modelo más moderno y más material, en el que predominaban los delitos económi$\cos ^{109}$. Sin embargo, como ya se ha explicado anteriormente, no estamos ante la delincuencia real, sino más bien ante aquellos delitos que mayor conflictividad creaban en el ejercicio del derecho de inmunidad. Es evidente que en el XVIII, ante el desarrollo del Estado borbónico, mucho más centralizado, en el que se trató de dominar y afianzar las fronteras y se buscó contar con una fuerza militar permanente y disciplinada ${ }^{110}$, los delitos de contrabando ${ }^{111}$ y deserción adquirieron una importancia que hasta entonces no habían tenido ${ }^{112}$.

11 (1995), pp. 103-121; Benoît GARNOT, «Une illusion historiografique: justice et criminalité au XVIIIe siècle», en Revue Historique, 276 (1989), pp. 361-379.

109 Respecto a esta polémica historiográfica: Daniel SÁNCHEZ AGUIRREOLEA y Félix SEGURA URRA, «Honor y marginalidad. Las razones para la violencia interpersonal en la Europa de los siglos XIV-XVII» en Memoria y Civilización, 2 (1999), pp. 349-361.

110 Fernando PUEll DE LA VILla, Historia del ejército en España, Madrid, Alianza Editorial, pp. 19-47.

111 Alberto ANGULO MORALES, «Kontrabandisten aurkako neurriak XVIII...

$112 \mathrm{El}$ abandono de la bandera era un mal endémico del ejército de los Austrias, debido, en parte, a una falta de organización que, entre otras cosas, no aseguraba el cobro de las soldadas.

Mundo moderno

Hispania Sacra 55 (2003) 
Los únicos refugiados entre los que existe un porcentaje considerable de personas ajenas a la comunidad del lugar sagrado en que se protegen, son los que cometen delitos de deserción y, en menor medida, robo. Más de la mitad son vecinos del lugar y el resto son o de pueblos cercanos, la mayoría, o vecinos del reino, o de la provincia de Guipúzcoa (según el lugar en el que nos encontremos). El porcentaje de extranjeros es mínimo y se trata en su gran mayoría de vagabundos y soldados desertores. Respecto a los lugares que acogían a los refugiados, en el siglo XVII, nos encontramos con que las ermitas tienen un papel importante, suponiendo un $26 \%$ del total, que pierde importancia en el XVIII (19\%), seguramente al aplicarse las leyes que restringían la consideración de lugar sagrado. Al contrario que las ermitas, los cementerios pasan de un $4 \%$ a un $13 \%$, debido a que se trata de un recinto impulsado en el XVIII ${ }^{113}$. El lugar de acogida dependía del modo en que se producía la entrada en sagrado. Si en una localidad alguien había cometido un delito y era consciente de que podía ser perseguido por la justicia, acudía inmediatamente a la iglesia parroquial (en el caso de un pueblo pequeño, a una iglesia cualquiera de la ciudad o a un convento), donde podía tener asegurado alojamiento y comida. El caso de las ermitas y también el de los cementerios era más típico de aquellas personas que eran perseguidas por la justicia y se tenían que meter en el primer sitio que encontraban, llegando a sujetarse a los barrotes, metiendo medio cuerpo dentro del recinto. Era muy normal que en el traslado de presos, el camino pasara por una ermita y así el reo quedaba protegido por ella ${ }^{114}$ : este es el caso del Santo Cristo de Andoáin (Guipúzcoa), situado en un puente de obligado paso ${ }^{115}$, al igual que la Basílica de la Trinidad de Arre, muy cercana a Pamplona, o la del puente de Caparroso.

La distribución geográfica de los pleitos sobre inmunidad está estrechamente ligada al control jurisdiccional que ejercen los tribunales eclesiásticos. Si se

Enrique MARTÍNEZ RUIZ, «El ejército de los Austrias», en Estudis, 27 (2001), pp. 15-16.

113 Proceso que culmina con la promulgación de una Real Cédula de Carlos III, el 23 de abril de 1787, en virtud de la cual se prohíbe la sepultura en las iglesias y se ordena el establecimiento de cementerios fuera de poblado. Además existe toda una serie tratados que secundan esta postura.

Ramón HUESCA, Nueva instancia a favor de los cementerios contra las preocupaciones del vulgo: tratado en que discurriendo por las épocas mas notables se demuestra que enterrar los muertos en los cementerios, fuera de los templos y de las poblaciones, es conforme a la piedad christiana y necesario a la salud publica, Pamplona, en la imprenta de la viuda de Ezquerro, 1792.

114 Muy significativo es el proceso ADP, 1962/2, en el que se traslada a Pamplona a un soldado acusado de deserción y éste se va arrimando a todas las ermitas por las que pasa el camino real: San Juan de Puente la Reina, Nuestra Señora del Perdón, la Magdalena en Guenduláin...

115 Este lugar se repite muchas veces, en 1712 alegan ser exceptuado. Cuando un cirujano acusado del homicidio de un clérigo, era llevado preso, se acoge a la ermita del puente. La defensa afirma que si se la conceden habría que hacerlo con todos los presos, puesto que no hay más remedio que pasar por allí. ADP, 1406/11. 
tiene en cuenta que la gran mayoría de las causas era iniciada por el fiscal, es lógico pensar que éste descuidara los territorios más alejados a su sede, como los valles pirenaicos y cantábricos, de donde apenas se conservan pleitos. Las causas procedentes de Guipúzcoa tampoco son muy numerosas y oscilan entre un $19 \%$ y un 25 según el siglo. La distribución geográfica y su evolución dependen también del tipo de delito: por ejemplo, el cambio más significativo fue el elevado número de pleitos que hacen referencia a Pamplona durante el siglo XVIII, un 29\%, frente al $7 \%$ propio del XVII. Esta evolución se debe a la ya comentada importancia que adquiere el delito de deserción durante el siglo XVIII, que afecta especialmente a una ciudad como Pamplona, una las plazas más importantes del norte peninsular. Otro dato a reseñar es la pérdida de importancia de ciudades como Tafalla o Estella, que pasan de sumar un $16 \%$ a apenas constituir el 3\% del total. De la Valdonsella, parte de Aragón perteneciente a la diócesis de Pamplona, no hay absolutamente nada, porque en este reino todos estos asuntos eran dilucidados, gracias al Fuero, por la justicia civil.

\section{CONCLUSIÓN}

El derecho de asilo se fue definiendo durante la Edad Media aunando las tradiciones germánica y romana, así como la propia evolución dentro de la doctrina de la Iglesia. En el siglo XVI se asentó con fuerza, aunque de manera muy diferente en cada uno de los territorios de la Monarquía Hispánica. Sin duda fue en Castilla y en aquellos reinos, como Navarra, más sujetos a su influencia jurídica, donde adquirió mayor poder. La lucha por el control de esta jurisdicción, los intentos de limitarla, anularla o expandirla se inscriben dentro de la misma lucha entre Iglesia y Estado. Una batalla legal, con episodios realmente graves, en la que se impuso el cada vez más poderoso Estado centralista. Sin embargo, hasta finales del XVIII, la Iglesia fue capaz de defender esta jurisdicción propia, creando una realidad cotidiana, el asilo a sagrado, que proporcionó amparo a todos aquellos que pretendían huir de la justicia.

Mundo moderno

Hispania Sacra 55 (2003) 